\title{
Experiências que tangenciam o (in)visível e a mobilidade: etnografias em diálogo
}

\author{
Denise Dias Barros' ${ }^{1}$ (iD 0000-0002-4145-3415 \\ Esmeralda Celeste Mariano² (iD 0000-0002-3619-5001 \\ 'Universidade de São Paulo, Programa de Pós-Graduação Interunidades em Estética e \\ História da Arte, São Paulo, SP, Brasil. 05508-220 - pgeha@usp.br \\ ${ }^{2}$ Universidade Eduardo Mondlane, Departamento de Arqueologia e Antropologia da \\ Faculdade de Letras e Ciências Sociais (FLCS), Maputo, Moçambique. Caixa Postal 257
}

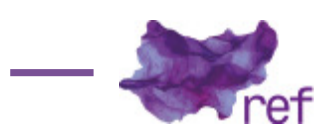

Resumo: O processo de entrecruzamento de perspectivas e análises de duas pesquisadoras é o foco da discussão deste texto. Nele são discutidas as inquietações e questionamentos diante de solicitações experimentadas durante o trabalho etnográfico caracterizado pela longa duração tanto entre os Dogon (no Mali) como entre os Tsonga (no sul de Moçambique). Nas experiências aqui retrabalhadas são indicadas nuances de apreensão de experiências ligadas à loucura, à incapacidade reprodutiva, à migração e a um conjunto de dinâmicas de saberes endógenos em situações de crise e sofrimento individual e social. Na análise, as autoras atentam para o movimento do imaginário e da criatividade, assumindo, de modo complementar, uma releitura reflexiva como maneira de cumprir travessias epistemológicas para o entendimento de questões densas de sentido e de ambiguidades que emergiram em estudos de campo. Tornou-se relevante para ambas as pesquisadoras o recurso a estratégias sensíveis para acesso ao mundo imaginal - desenho, fotografia e construção fílmica -, inscrevendo produções expressivas na interpretação antropológica como possibilidades interculturais no contexto do trabalho etnográfico. As referências culturais e epistêmicas geram percepções contrastantes, por vezes ininteligíveis, demandando recurso a linguagens não lineares no que concerne a noções ligadas aos domínios do não visível e a formas de elaboração da mobilidade em meio às sombras lançadas nas construções intersubjetivas.

Palavras-chave: etnografia, loucura, práticas terapêuticas, mobilidade humana, Tsonga/Moçambique, Dogon/Mali

\section{Experiences that tangent the (un) visible and mobility: ethnographies in dialogue}

Abstract: The process of cross-referencing perspectives and analyzes of two researchers is the focus of the discussion of this text. It discusses the requests issues during the ethnographic work, characterized by the long duration, both between the Dogon (in Mali) and between the Tsonga (in the south of Mozambique). New understandings emerge from experiences linked to madness, reproductive incapacity, migration and a set of endogenous knowledge dynamics in situations of crisis and individual and social suffering. In the analysis, the authors look for the movement of the imaginary and the creativity, assuming, in a complementary way, a reflexive re-reading as a way to fulfill epistemological crossings to the understanding of dense questions of sense and ambiguities that emerged in field studies. It became relevant for both researchers to use sensitive strategies for access to the imaginal world - drawing, photography and film construction -, inscribing expressive productions in anthropological interpretation as intercultural possibilities in the context of ethnographic work. Cultural and epistemic references generate contrasting perceptions, sometimes unintelligible, requiring the use of non-linear languages in terms of the notions related to the domains of non-visible and forms of elaboration of mobility in the midst of the shadows cast in intersubjective constructions.

Keywords: Ethnography; Madness; Therapeutic practices; Human mobility; Tsonga/Moçambique, Dogon/ Mali 
Eu atravesso as coisas - e no meio da travessia não vejo!

[...] o real não está na saída nem na chegada: ele se dispõe para a gente é no meio da travessia. Guimarães ROSA (1986, p. 26-52)

\section{Introdução}

Muitas vezes, observamos, com certa perplexidade, as transformações pelas quais atravessamos como se estivéssemos além ou aquém de seus dilemas; outras vezes, separamos a pesquisa do lócus a partir dos seus enunciados e estabelecemos clivagens entre dimensões existenciais e políticas. Este texto responde a percursos construídos pelas autoras deste artigo em pesquisas conduzidas em locais e períodos distintos, mas que convergem em diálogos sobre conhecimentos que necessitam interrogar a si mesmo, em inquietações sobre intersubjetividades, artes e antropologia na busca de caminhos para pensar as indagações e demandas culturais em seus contextos. A experiência etnográfica pode criar campos de estabilidade afetiva, de criatividade, de trocas (conectividade) e, portanto, de possibilidades ainda não pensadas de vida.

As formas sensíveis da expressão escrita, incorporando imagem, espiritualidade e horizontes, são intersubjetivas e exigem o exercício da reflexividade. Interessa, aqui, perguntar se a diversidade dos modos e linguagens de expressão continua a afetar, pelo negativo, a construção da interpretação antropológica que atua metodologicamente alicerçada na dialogia. Em outras palavras, na escuta e busca de entendimento de que as percepções alteram significativamente a ideia de invisibilidade e seu estatuto de e no real, assim como as configurações de espacialidades e mobilidade: movem-se pessoas, coisas, símbolos e movem-se os espaços (Denise BARROS, 2004). A ruptura epistemológica e hierárquica, de gênero e de lugar, permite hoje entrelaçar uma pluralidade de modos de sermos nativas e estranhas ou insiders e outsiders (Esmeralda MARIANO, 2017), originárias de lugares plurais, móveis e criadores de perspectivas maleáveis? Uma antropóloga moçambicana e uma brasileira, em Moçambique ou no Mali, a crítica e desconstrução para abrir as metodologias de escuta e de transformação da própria percepção de temas complexos - como são as razões e motivações que encenam o não imediatamente visível aos olhos e que geram o que são mobilidades - podem transformar as noções de local aprisionado à de imobilidade, do nativo destituído de historicidades, aprisionado a um lugar de enunciação das margens. Como sugerido por Vincent CRAPANZANO (2004), é heuristicamente importante conceber horizontes difusos a partir da diferenciação entre experiência de interpretação para viabilizar a compreensão da dialética entre abertura e fechamento integrantes tanto da experiência humana como da compreensão antropológica. A construção da reflexão pela construção de narrativas fílmicas, fotográfica ou desenhada permite a composição e a justaposição, também, na escrita, pluraliza o texto e amplia os campos de aproximações entre etnografias realizadas em temporalidades e espacialidades distintas. Nossa experiência de escrita que justapõe experiências etnográficas, possível graças ao projeto PROÁFRICA/CNPq, ${ }^{1}$ abriu horizontes novos de colaboração e partilha além do texto.

A apreciação crítica da construção do conhecimento no pensamento antropológico sobre as relações de alteridade e sobre as culturas tem tido constante interação entre artes, humanidades e ciências sociais, desde Writing Culture (James CLIFFORD; Georges MARCUS, 1986). As parcerias, como a que une as autoras deste trabalho, têm sido igualmente instigantes no sentido de pôr em questão as assimetrias múltiplas que exercemos no modo de construir o conhecimento, sobre as diferenças na mobilização para o entendimento da pesquisa de campo.

A noção de reflexibilidade conheceu um interesse renovado nos anos 1980, no contexto das ideias de desconstrução dos postulados de verdade da ciência. Entendemos que a compreensão dos fenômenos não é reflexo do real, mas "construção do espírito que levanta problemas" (Edgar MORIN, 1987, p. 19), sendo, portanto, ao mesmo tempo objetiva e subjetiva.

\section{Preocupações fundamentais e seus contextos de pesquisa}

Que traz o contemporâneo para o conhecimento antropológico e para as expressões estéticas na África que nos permitem pensar o mundo e a nós? Não há como separar a arte dos tecidos morais da sociedade. "Arte é o que governa, incluindo o que se chama de criatividade artística, e a totalidade da noção de beleza que não pode ser separada do significado de cultura" (John

\footnotetext{
${ }^{1}$ Artigo produzido no âmbito das pesquisas e reflexões promovidas pelo projeto PROÁFRICA/CNPq - "'A vizinhança nas entrelinhas': alianças e conflitos, trocas (des)iguais e cooperação entre Moçambique e África do Sul" (projeto selecionado na Chamada MCTI/CNPq n 46/2014 - Programa de Cooperação em Ciência, Tecnologia e Inovação com Países da África - PROÁFRICA), coordenado por Laura Moutinho. Integraram a pesquisa: Brigitte Bagnol, Esmeralda Mariano, José Ricardo Ayres, Lilia Schwarcz, Paulo Sérgio da Costa Neves, Pedro Lopes e Rita Simone Liberato, tendo sido incorporadas ao longo do processo as pesquisadoras Denise Dias Barros, Carla Braga, Solange Rocha, Gabriela Calazans e Susan Holland-Muter.
} 
Ayotunde Isola BEWAJ, 2013, p. 98). Nossa abordagem à estética enfatiza as ligações entre as experiências artísticas e cotidianas, ao invés de separações conceituais dos dois domínios, como é caracteristicamente encontrado nas artes de elites euro-americanas. Uma peça de arte ou objeto artístico pode encapsular formas de existir e estar no mundo e permitir "a imaginação de um novo mundo em que se possa habitar em suas múltiplas corporificações" (Zethu MATEBENI, 2017, p. 38).

As reflexões do filósofo italiano Giorgio AGAMBEN (2009) oferecem sugestões para nossas travessias entre tempos e espaços quando propõem que o contemporâneo se encontra na experiência de ver além da obscuridade do próprio presente. "Escrever mergulhando a pena nas trevas do presente", perceber a luz no escuro, não se deixando cegar pelas luzes do tempo em que se vive para não cessar de buscar compreendê-lo e de interpretá-lo. Aqui, nosso maior desafio está em (entre)ver no recente as "assinaturas do arcaico" (AGAMBEN, 2009, p. 69). Assim, ser contemporâneo é ser capaz de ir à origem, mergulhando na obscuridade das luzes do presente. Nesse sentido, as experiências humanas vividas no passado da África, com sua força e capacidade de manter a complexidade e a tensão da arte e da estética no viver, possibilitam compreender enigmas de indagações de nossos espaços contemporâneos.

As relações entre as estratégias de campo e o debate sobre os lugares de enunciação das pesquisadoras necessitam ser consideradas como parte do campo e da análise das informações interpretadas. E mesmo que diversos autores - tais como Georges MARCUS e Michael FISCHER (1986); Lila ABU-LUGHOD (1986); CLIFFORD; MARCUS, 1986; Pierre BOURDIEU e Loïc WACQUANT (1992); James CLIFFORD (1998) e Renate Duelli KLEIN (1983) - tenham trabalhado sistematicamente nas últimas décadas sobre tais questões, há ainda lugares silenciados e outros que exigem atenção permanente. Manter atitude cautelosa é, muitas vezes, antitética à imagem do êxito; em princípio o/a pesquisador/a ocupa o lugar da autoridade e de conhecedor do seu campo (CLIFFORD, 1998).

As fragilidades das relações e a clivagem de interesses mantêm-se usualmente separadas, disfarçadas ou negadas no universo dos resultados. Há preços altos a pagar na produção de conhecimento. Nas universidades sul-africanas, ativistas na academia foram encarcerados e intimidados por expressar pontos de vista diferentes da instituição de controle dos corpos. Matebeni (2017), de forma eloquente e corajosa, busca novas linguagens e maneiras de rebater os regimes normalizadores da produção do conhecimento acadêmico que desconectam o projeto intelectual das realidades vividas pelas pessoas, usando a linguagem visual, metáforas visuais, das artes para falar sobre as múltiplas sexualidades e da diversidade de gênero, evidenciando a criatividade das linguagens contemporâneas.

Duas teses fundamentam nossa discussão: a de que nenhuma sociedade é extemporânea e nenhuma sociedade entrega-se ao fechamento, desenhando um campo fora do movimento dos espaços. O arcaísmo e o descentramento dos acontecimentos espelham relações de dominação dos lugares de enunciação.

O historiador de Camarões Achille MBEMBE (2010) questionou a descolonização (política, econômica e simbólica) em África e tem aberto intensa reflexão sobre uma epistemologia da África e não sobre África. O autor nos convida ao entendimento de África fora da noção de ausência ou de falta. O autor insiste que a descolonização exige um processo partilhado, não havendo descolonização da África sem processo de autodescolonização e sem desimpregnação de lógicas e conceitos desumanizantes e desqualificadores. Nessa mesma coletânea de estudos a temática é abordada no artigo de Paulo NEVES et al. (2019), com ênfase no campo da educação na África do Sul, no Brasil e nos Estados Unidos. O escritor queniano Ngugi Wa THIONG'O (1986) já havia evocado a valorização da língua local na sua obra Descolonizing the mind: the politics of language in African literature, assinalando que a escolha e o uso que se faz da língua são centrais na definição que as pessoas dão de si, em relação ao seu ambiente natural, social, e em relação ao mundo. No processo de colonização dos países africanos, a área de dominação mais poderosa foi a mente do colonizado, um controle através da desvalorização ou destruição da cultura, que influencia a maneira como se percebe a si mesmo e a relação que se tem com o mundo (THIONG'O, 1986, p. 16). O processo de descolonização da mente deve partir da produção do conhecimento, que valoriza as formas artísticas, criativas, visuais e orais em articulação com os múltiplos campos de saberes.

\section{Retorno à problematização da etnografia: paralelismos e convergências}

Revisitamos nossas experiências sobre o invisível e sobre a mobilidade, ambas conectadas pela aceleração de transformações relacionais tecnológicas que afetam cotidianamente os horizontes imaginativos e as formas dramáticas (rituais) de narrativas orais e em linguagens visuais.

A reflexão, neste texto, buscou aproximar e interligar experiências que emergiram, sobretudo, em estudos de campo de longa duração, que pediram uma reconsideração conceitual em meio 
a percepções fugidias que encontram ancoradouro mais seguro em linguagens complementares como é aqui o campo das imagens em contextos etnográficos, ${ }^{2}$ sejam estas na forma do desenho, em fotografia ou mesmo em construção fílmica. Trata-se de cenários reflexivos multissituados (MARCUS, 1998); são, ao mesmo tempo, travessias intersubjetivas que mobilizam a imaginação, além de dimensões cognitivas. Tais reflexões ligaram nossa apreensão de interações, contextualizações fundamentais nos processos de compreensão (Gregory BATESON, 1981) que se arquiteta nos efeitos de embaralhamentos entre arte e vida em marcha e movimento, própria da altermodernidade, com apoio na reflexibilidade transcultural e no debate sobre negociações culturais entre formas de vida (Nicolas BOURRIAUD, $2011 \mathrm{a} ; 2011 \mathrm{~b}$ ).

No percurso de Barros, há deslocamentos que remetem à "ferramenta e doutrina intelectual partilhada" (MARCUS, 2004, p. 135) e às finalidades (imaginadas) do estudo, sobretudo no caso da pesquisa conduzida entre 2003 e 2005 sobre mobilidades em diferentes gerações de homens e de mulheres entre a vila de Songho e a capital do Mali, Bamako (BARROS, 2010) que se traduziu, igualmente, no filme Ganda Amaji (Sonhar a cidade), realizado em parceria com Gianni PuzzO (2006). O processo de criação foi gerado no esforço da dialogia entre a pesquisadora e uma parte da população de Songho, movimentando-se e ampliando redes de relações e campo de trabalho na capital do país.

A primeira viagem da pesquisadora ao Mali ocorreu em 1993 a fim de viabilizar a pesquisa de doutorado, "Itinerários da loucura em territórios Dogon", no âmbito do Programa de PósGraduação em Sociologia na Universidade de São Paulo. Na ocasião, foi possível participar de um seminário nacional sobre as medicinas originárias de diferentes sociedades do país. Foram quinze dias de convívio com terapeutas, especialistas em tratamentos de diversas modalidades de adoecimentos e emergência de infortúnios e sofrimentos existenciais. Depois, houve o estágio no Centro Regional de Medicina Tradicional da Divisão Nacional para conhecer os estudos realizados, principalmente nos anos 1980, no vasto campo do sofrimento psíquico. Entre 1994 e 1997, a pesquisadora permaneceu na região do planalto e falésia Dogon. Outras pesquisas etnográficas sobre temáticas diversas - como turismo, mobilidade, peregrinação a Meca - foram concretizadas na mesma região até 2011 , tendo sido interrompidas devido à guerra que impediu a presença de pessoas estrangeiras na região central do Mali/Planalto Dogon.

Nos estudos iniciais, era intento conhecer os caminhos do cuidado, do entendimento das modalidades presentes de sofrimento psíquico e as possibilidades que se abriam, naquele contexto cultural e social, a pessoas que, porventura, fossem caracterizadas por essa situação de adoecimento ou de aflição. Não se tratava, portanto, de um estudo médico-psicológico, mas sim antropológico. Ao conviver e interagir com diferentes terapeutas e adivinhos foi possível construir o trabalho naquela região sendo, no ano seguinte, recebida pela Divisão Nacional de Medicina Tradicional, na pessoa do professor Arouna Keita. Houve ainda o apoio da ONG ORISS, sobretudo, de Piero Coppo e de Lelia Pisani. Eles haviam sido fundamentais na formulação das preocupações em saúde mental no contexto dos conhecimentos praticados no planalto Dogon, região central do Mali (África do Oeste). Foram dois anos de imersão em um conjunto de experiências transformadoras e formadoras de modo de trabalhar que geraram, igualmente, novas dimensões existenciais.

Parte do trabalho conceitual não poderia prescindir do esforço de partilha sensível e imagética. Assim foi com a apreensão das narrativas que denominamos contos, uma forma de palavra que veicula conhecimento por meio de gênero criativo e, até certo ponto, lúdico. O estudo com os desenhos desdobrou-se, sobretudo, das rodas de contos sobre a loucura e vivência e grande número de cenas rituais, cotidianas ou ligadas ao ciclo agrícola, bem como aos cuidados com aqueles ou aquelas que adoecem. A prática ritual é concebida como formas relacionais que estabelece redes complexas e entrelaçadas que se condensam pela e com a ação, além de alimentar a identificação entre seres nelas implicados (Michael HOUSEMAN; Carlo SEVERI, 1994, p. 205-206). Há ainda uma pluralidade de relações cotidianas ou que permanecem (mutuamente excludentes), que se repousam ou se condensam na/pela ação ritual. É um conceito síntese de linguagens em movimento e como "veículo de simbolização e instrumento de estratégia social" (HOUSEMAN; SEVERI, 1994, p. 195).

Após ouvir os registros em áudio de contos, um jovem desenhista recriou sequências de imagens, restituindo vinte narrativas, utilizando, para isso, caneta hidrocor sobre papel sulfite. Os contos foram de difícil acesso e só foi possível adentrar esse universo depois de muito percorrer o diálogo com terapeutas e adivinhos. A palavra confere existência e vida, sendo dotada de qualidades de proteção, e age de modos diferenciados para favorecer a aceitação do outro quando em uma condição de estrangeiridade ou contra o medo e a atuação dos seres não visíveis ou mesmo de inimigos voluntários ou não. Sem a possibilidade de compreender a língua,

${ }^{2}$ O texto retoma criticamente análises apresentadas pela primeira autora durante a 29 a Reunião Brasileira de Antropologia, realizada entre os dias 03 e 06 de agosto de 2014 em Natal/RN, no Simpósio Especial 015, intitulado Transnacionalidade, pesquisa de campo e visualidades. 
os limites foram presentes em todos os momentos, aumentando a premência de análise do sensível e de auto-observação. Era uma ressocialização profunda, desde a mais básica saudação diária e palavras-chave, lentamente incorporadas, até a negociação para tornar possível encontrar um lugar possível. A barreira linguística, mas também epistêmica, permaneceu sendo uma limitação desafiadora.

Os registros de conversações, com transcrição das línguas Dogon (ou pular/fula, por vezes) e traduções (realizadas por um grupo de três colaboradores) foram negociados e partilhados quando as relações permitiam. Assim foi, também, com a filmadora, usada como caneta, como máscara e, até, como refúgio. Mas ela foi inúmeras vezes esquecida para viver outras dimensões das relações e da experiência. Era ainda tempo de filmadoras de formato Hi8 e de fotografias analógicas. O som, inicialmente, ruído, tornou-se musicalização, sonorização e harmonizou passagens. O gravador, no caso das rodas de contos, foi percebido como modo de registro a ser partilhado, pois alguns queriam para levar à rádio local a fim de serem transmitidos para interlocuções a distância. Outros desejaram ter para si. O áudio pode ser levado a um desenhista que escutou e recriou uma série de vinte contos. Estes desenhos foram preciosos para entrever percepções do mundo espiritual-invisível, dificilmente acessível à pesquisadora.

Os primeiros contatos com as pessoas de Songho, localidade do planalto Dogon, ocorreram de modo intenso entre 1994 e 1996 em grande número de viagens. Inicialmente, o trabalho teve foco nos itinerários de pessoas consideradas keege (dentro do largo espectro do que podemos chamar de fenômeno da loucura ou do sofrimento psíquico) que não estivessem sob tratamento. Desta fase emergem as questões relativas ao campo do não visível presentes na existência cotidiana e, sobretudo, nas suas dimensões mais próximas ao aflitivo e ao sofrimento. Mas, após os anos 2000, outro programa de estudos teve início voltado para a representação francesa sobre a sociedade Dogon na televisão e na criação de páginas da web e para os fatores de transformação social a partir da vila da Songho, migração sazonal e modalidades de extraversão (Jean-François BAYART, 2006), consideradas de modo aprofundado em diferentes gerações a partir de uma localidade. Barros, Aghi BAHI e Paula MORGADO (2011) dedicaram-se, no campo aberto pelo desenvolvimento da web, aos caminhos da representação da sociedade Dogon com substantivação de identidades. A peregrinação para Meca, realizada em longas etapas de mobilidade, partindo de Songho, foi analisada por Barros e Mustafa ABDALLA (2014).

O trabalho teve como polo enunciador a vila Songho para interrogar questões relativas à mobilidade de pessoas em seus entrelaçamentos entre vila e os diferentes horizontes, como a capital do Mali, Bamako. Neste período a busca de compreensão partilhada intensificou a necessidade de outras modalidades de construção do conhecimento, geralmente envolvendo entrevistas, observações e discussões. Uma oportunidade surgiu quando um jovem propôs a realização de um filme cujo argumento inicial abordava a história da migração sazonal a partir das experiências vividas por sua geração naquele local. Assim, nascia a ideia do que viria a ser o filme Ganda Amaji. A narrativa, centrada num jovem que migrava da aldeia para a capital, recobriu debates sobre anseios, desafios, dilemas, conquistas e dificuldades e tornou muito mais densa nossa compreensão das relações entre vila e cidade e de como, ao longo do tempo, havia sido tecida uma trama de vais-e-vens existenciais, linguísticos, culturais e económicos.

A trajetória de Esmeralda Celeste Mariano possui esse mesmo tipo de curiosidade e de vontade de aprender, conduzido no deslocar-se para percorrer múltiplos caminhos na pesquisa realizada em Moçambique, particularmente na região Sul. Este trabalho conectou fragmentos de diferentes saberes (da filosofia, da linguística, da biomedicina) para permitir a compreensão de fenômenos e dramas sociais, os sentidos e as ações para fazer face às condições da existência do ser e estar no mundo. Na maioria das vezes, foi um caminho contracorrente em relação aos discursos e práticas das instituições hegemônicas em sua pressuposição de deter o conhecimento e poder de intervenção no controle dos corpos e do mundo. Por exemplo, quando, nos anos 1980, enquanto - Ministério da Saúde Moçambicano lançava a campanha global no local para o planejamento familiar como medida coletiva e corretiva malthusiana de controle de número de filhos, com intenção de reduzir as mortes neonatal e materna, sua atenção se orientava em direção à compreensão de racionalidades "outras", da "escolha" pessoal (deliberada ou não) por um "elevado" número de filhos, do significado subjetivo da reprodução biológica e social, as implicações individuais de um projeto reprodutivo inalcançado, geralmente, experiência dramática e traumática. Como tal, o estudo dos fenómenos da reprodução biológica requereu da pesquisadora assumir um compromisso que implicava não somente a capacidade de auscultar e observar as experiências das pessoas com empatia e compaixão, com um posicionamento ativo e moralmente engajado para alguns, entendido como algo assustador e utópico: "pensas que vais virar o mundo?", diziam alguns colegas.

O simbolismo e a interface: terra-mulher e fertilidade traçaram o seu processo inicial à pesquisa, em 1998 (com permanência ininterrupta de três meses) em Matutuine (Djabissa), na província de Maputo, como parte de trabalho de campo para obtenção da licenciatura em 
"Letras e Filosofia" - com orientação em Etno-Antropologia. Múltiplas foram as experiências da pesquisa que a memória gravou. Uma delas, quando preparava a ida ao campo, um colega e amigo cientista social questionou o local do estudo. "Não tens medo de ir à Matutuine? É lugar de feiticeiros, cuidado, podes não voltar!". Distanciada de estereótipos, permaneceu em silêncio, imaginando que o campo de pesquisa se abria para a apreensão de outras narrativas e da dimensão das invisibilidades, a partir das experiências de diferentes atores sociais.

A escritora nigeriana Chimamanda ADICHIE (2009), em viva-voz, chama-nos atenção que "o problema com estereótipos, não é que eles sejam mentira, mas que eles sejam incompletos. Eles fazem uma história tornar-se a única história". Assim, a imagem sobre a feitiçaria e os lugares dos feiticeiros, certamente, também pareceram não ser a única história e era necessário captar outras representações sobre os feiticeiros.

Mambone, uma localidade no distrito da província de Inhambane, Magude, no distrito da província de Maputo, é considerada como uma das regiões no Sul de Moçambique onde predomina a feitiçaria. Ali foram realizadas as pesquisas de Esmeralda Mariano com terapeutas, alguns deles conotados como feiticeiros, ou especialistas em antifeitiço. Obviamente, ninguém assume ser feiticeiro. A escolha do local, no caso de Matutuine, foi alicerçada pelas condições materiais e humanas disponíveis para realizar a pesquisa. Através do contato de um amigo, tinha garantias para interagir com os habitantes da região. Parece importante destacar a razão subconsciente para conhecer a região dos Tembe (Matutuine), local eleito para iniciação ao campo. Lugar de origem dos antepassados míticos da pesquisadora, do seu avô materno de sobrenome Tembe. Mais tarde, em 2001, com permanência mais prolongada (seis meses), continuou a pesquisa em Magude, dessa vez no lugar de origem da avó materna, dos Khosa. Sua mãe entreviu seus movimentos e circulações nesses lugares como "não por acaso". A aproximação aos locais de origem materna foi expressa pelos seus interlocutores e sua mãe (que, como um dom, acompanhou-a e colaborou na pesquisa em 1998 e em 2001), como valorização do conhecimento endógeno, ontologicamente em busca da consciência da sua existência, e, também, de proteção dos antepassados. Estes pensamentos sugerem que a reflexão é sobre a existência e sobre todos os seus meios através dos quais a existência pode ser compreendida (Francis NJOKU, 2005).

Inicialmente, foi adotado um método bastante descritivo, a partir do trabalho de campo prolongado com observações e entrevistas em profundidade com pessoas inférteis aflitas, e com terapeutas tradicionais que reconheciam a ineficácia terapêutica na sua arte de cuidar. Terapeutas e pacientes entreviam as limitações da reificação da etnografia, de fazer uma pesquisa baseada na simples catalogação etnográfica das experiências e dos mecanismos de gestão do sofrimento. Ao mesmo tempo, no espaço acadêmico, as expetativas versavam sobre a teorização. A combinação das expetativas, práticas e teóricas, orientou para uma análise em perspectiva interpretativa-crítica (observando as dinâmicas das relações de poder, a intersecção entre política e economia na definição de escolhas, possibilidades e formas de vida) e a pensar em ações e propostas práticas de cuidados de saúde. A pesquisa aplicada e ativista nos círculos académicos mais elitistas é subvalorizada e reputada menos científica. Foi a partir de 2008 que, no engajamento e interação com atores das ciências biomédicas (ginecologistas-obstetras, enfermeiros/as), biólogos e especialistas da bioética, terapeutas tradicionais e mulheres e homens aflitos, no âmbito da pesquisa de doutorado, que deu à sua pesquisa um rumo mais participativo e orientado para a ação. Os diferentes atores da pesquisa assumiam contemporaneamente posições de pesquisado/ pesquisador e, reflexivamente, partilhavam suas experiências individuais e dilemas profissionais. Não é surpreendente que na interação interdisciplinar, no contato entre atores com experiências e proveniências diversificadas surjam questionamentos sobre a fiabilidade e validade dos métodos e análises da pesquisa. Os contrastes foram especialmente enfatizados nas configurações específicas do valor e significados do conhecimento biomédico e endógeno sobre o funcionamento do corpo biológico e dos processos de ajustamento e reequilíbrio. Há espaços mais facilmente permeáveis ao cientista social (sociólogos e antropólogos) e inacessíveis aos biomédicos.

Os significados das experiências da doença e do mal-estar nem sempre encontram correspondência entre quadros cognitivos biomédicos, por isso, são ignorados pela instituição biomédica. Mas a diferença, o desconhecido, também não passam despercebidos, e tornam-se objeto de interesse, de especulação, de compreensão em espaços permeáveis.

Uma premissa deste trabalho do campo era a de estar o mais próximo possível dos interlocutores, para captar as experiências imediatas, aberta a entender [a pesquisadora], utilizando múltiplas linguagens que suavizam a interação, e que permitissem "entrar" em seus universos, compreender as dimensões da intimidade e dos segredos. Para as mulheres terapeutas-médicas tradicionais, a pesquisadora era "quase infértil" por ter tido um "só" filho. Todavia, as médicas tradicionais perceberam algumas afinidades no universo feminino, e classificaram-nas como alguém com sensibilidade e com atenção aos seus sentimentos e inquietações. Sentiram que estava à vontade para discutir com elas (terapeutas) questões sobre infertilidade, sentada numa esteira no local de consulta do terapeuta, ou num centro de saúde com um ginecologista. Sua 
ligação com os profissionais de saúde foi, outrossim, sentida pelas médicas tradicionais como um espaço ideal para construir a relação de confiança, de negociação para a partilha e produção híbrida de saberes e cuidados. O uso da competência cultural, ou seja, devota a pesquisar e a analisar as expressões idiomáticas, e os códigos culturais do mal-estar e doença não se restringiu apenas nas consultas de ginecologia nos hospitais, mas também, decifrando e interpretando os diagnósticos médicos e transmitindo as mensagens aos pacientes. No entanto, importa ter em mente que "um exercício de tradução intersubjetiva, de falar pelos outros e a partir de seu ponto de vista, nossa arrogância, pode causar infinitas dificuldades morais e filosóficas" (Jean COMAROFF; John COMAROFF, 2010, p. 15) na representação social e da experiência humana. O enfoque mais apropriado, de acordo com estes cientistas sociais, "consiste na representação e na busca de compreensão de mundos coletivos - a dialética, no espaço e no tempo, das pessoas e dos lugares, das ordens e dos eventos, na interpretação de fenômenos sociais, e não na procura interminável de artifícios textuais para exorcizar o fato de que nossos relatos não são transparências realistas" (COMAROFF; COMAROFF, 2010, p. 16).

O exercício da observação, escuta, tradução e interpretação para compreender e responder aos anseios da vida, na pesquisa, se estende e se complexifica no universo dos terapeutas tradicionais. A hermenêutica foi aportada como possibilidade de revelação profunda dos significados, o que implica tornar explícito o implícito, abertura às múltiplas linguagens e premissa à criatividade. Achille MBEMBE (1997) lança o desafio para a produção do conhecimento que valoriza as formas artísticas, criativas, visuais e orais em articulação com os múltiplos campos de saberes. De facto, a circulação entre espaços, a interação entre sujeitos e objetos nos processos de cura estimulam a nossa percepção visual a deslocar o olhar dos corpos para os objetos e viceversa, e a representar as formas de vida social, que são incomensuráveis, paradoxais ou excessivas.

Para compreender a relação complexa e variada entre sujeito-objeto, a análise de um discurso político se presta para uma breve contextualização dos lugares e pessoas. Em Moçambique, nos anos noventa, foi exaltada a celebração do terapeuta local como depositário de um património cultural nacional, na afirmação do antigo presidente Joaquim Chissano: "Nós queremos que a autoridade tradicional exista!" (Harry WEST, 2009, p. 295). Autoridade tradicional refere-se aos atores legitimamente reconhecidos, pelo Estado e nas comunidades, com funções de liderança (política, administrativa ou religiosa). Os terapeutas tradicionais constituem parte deste grupo, ainda que seu campo de conhecimento se resuma apenas à dimensão da fitoterapia, da administração de substâncias, cujos princípios ativos podem ser isolados, testados e validados nos laboratórios científicos (WEST, 2009, p. 306). Portanto, confina-se o valor material do conhecimento endógeno, para fins comerciais ao domínio da indústria farmacêutica, excluindo o seu valor ontológico e cosmológico. Pouco se sabe sobre a simbologia do poder das autoridades tradicionais, a maneira como as pessoas projetam suas casas, seus utensílios, seus apêndices da vida diária, formas de adoração que expressam as relações sociais e com o mundo, e que refletem na relação com as artes (BEWAJI, 2013, p. 271).

O encontro das pesquisadoras em São Paulo, em 2016, no âmbito do primeiro workshop do Projeto PROÁFRICA/CNPq - "A vizinhança nas entrelinhas", proporcionou a revisão de uma série de elementos que marcaram ambos os percursos de pesquisa, cruzamentos de percepções e experiências. Aceitamos o desafio de dialogar e refletir sobre a análise dos objetos e dimensões do real que nos interrogavam que emergiram de formas de expressão estética na sua interlocução entre imaginário, compreensão da pessoa, de corpos, saúde e doença. A paixão pelo detalhe no trabalho de campo de ambas as pesquisadoras cresceu gradualmente, mas por muito tempo ficou presa na intenção de reelaboração, compondo, de certo modo, um enigma e uma dimensão de grande desafio epistemológico adiado. Despidas de presunção epistemológica no campo da sociologia da arte, mas augurando que nosso encontro abra caminhos para leitura, reflexão e compreensão de outras formas textuais que não sejam apenas a escrita ou simplesmente a linguagem verbal a ditar os objetos de conhecimento. De salientar que a atribuição de uma essência artística aos objetos não se trata de "devoção primitiva" aos feitiços, ou como meros símbolos de uma cultura arcaica (COMAROFF; COMAROFF, 2010), mas como uma forma de descrever situações e relações de poder, situar significados e o entrelaçamento destes com a vida.

\section{Entre narrativas no limite de oralidades e visualidades}

O entendimento sobre invisibilidades que expressam os nyanga no sul de Moçambique e as diversas modalidades de se fazerem presentes os yebe-ne - seres invisíveis que povoam a loucura entre os Dogon - formam as passarelas de nossas indagações mútuas. Temos mesmo que questionar: o que se sabe das outras dimensões do saber da medicina local, para além do visível? Como e quem as pode conhecer? Estas questões surgem na pesquisa, e ainda estamos em busca de explicação e compreensão.

No espaço da mais prestigiada Faculdade de Medicina da Universidade Eduardo Mondlane, em Maputo, Moçambique, que a pesquisadora e docente frequenta desde 2002, na 
parte interna da entrada principal do edifício, está visível a obra de arte de um dos proeminentes artistas contemporâneos moçambicanos (Malangatana Ngwenya). Sua obra ilustra cenas de vida e das práticas da medicina endógena, espelhando as vivências do autor e de muitos moçambicanos. Especialistas de arte africana sustentam que a essência da arte, em várias partes do continente, cria a ilusão de pensarmos que estamos a ver, quando não vemos. Não surpreendentemente, alguns dos objetos mais respeitados raramente são vistos. Provavelmente, as cenas retratadas no mural - representando terapeutas tradicionais em atividade - sejam percebidas como exóticas, meramente decorativas e privadas de significado. Além disso, o encontro estético não é apenas multissensorial, móvel e performativo (Mary NOOTER, 1993); congrega outros sentidos além da visão. Sobre qual leitura e compreensão têm os cientistas da biomedicina em relação à imagem e à medicina local, e sobre o tipo de interações que são estabelecidas entre os saberes, ainda há muito para percorrer. Os cientistas sociais que empreendem esforços na busca de compreensão das dimensões não materiais na medicina local são julgados tolerantes e passivos defensores de crenças e práticas mágicas e obscurantistas.

O reconhecimento do mundo espiritual-invisível como parte existencial do indivíduo e da vida quotidiana é uma das dimensões realçada neste artigo. A aquisição do conhecimento terapêutico implica aprender a usar e a controlar o poder dos antepassados, "possuí-los" e aprender a controlálos é, simultaneamente, a transferência do conhecimento e a recuperação ou criação da identidade (Robert THORNTON, 2009). Estar curado e ser capaz de curar simboliza a fusão do saber estar com os espíritos e ser nas esferas dos vivos. Esse percurso pessoal de pesquisa tem sido, também, um processo curativo, no sentido de busca de preenchimento de hiatos na compreensão do mundo. A atenção da pesquisadora aos dilemas da vida não passou desapercebida entre as terapeutas, elevou a confiança e aquiescência, por isso, disseram-lhe: "no final deste trabalho serás nyanga; o nosso desejo é vestir-te as roupas do espírito Ngoni". ${ }^{3}$ Esta afirmação foi luz verde para participar, observar rituais terapêuticos e refletir sobre perspectivas ausentes, não vistas e não ditas da incapacidade reprodutiva, baseadas em histórias locais, epistemologias e conhecimentos ocultos, para retomar as críticas de Archie MAFEJE (2001) de modelos de entendimentos estabelecidos.

À medida que se viabilizara o acesso aos rituais terapêuticos "secretos", apanágio de alguns, o sentido e a capacidade de memorização natural dos eventos foi se reduzindo, e aumentada a necessidade de fazer outros recursos, artificiais e tecnológicos, para o registro mais detalhado e apurado e posterior análise e discussão com outros colegas. A câmera fotográfica, a filmadora e o gravador de voz formaram os objetos tecnológicos que auxiliaram o registro de campo, com respeito aos princípios éticos (confidencialidade e anonimato), devidamente acautelados. Primeiro com o consentimento individual dos atores envolvidos, resultante da relação humana estabelecida, e segundo, conjugando o consentimento formalmente obtido com os mesmos participantes, num formato escrito, de acordo com as normas da bioética para a saúde do Ministério da Saúde em Moçambique.

Na experiência no campo, as observações das atividades, dos eventos, das interações e dos objetos nem sempre são enunciadas, mas carregadas de significado religioso e cultural. As inter-relações subjetivas e entre as pessoas e o mundo espiritual se ligam às formas expressivas (orais, visuais, rituais, performáticas etc.).

A incisiva presença dos espíritos dos antepassados na intuição e nos sonhos que compõem o processo formativo e de iniciação terapêutica constitui um caminho heuristicamente rico para aprofundar a compreensão sobre seus/nossos entendimentos, sobretudo, em situações de crises pessoais e sociais, e, igualmente, diante das constantes mudanças que se operam na história. Nesta esfera, há dúvidas e inseguranças geradas pela presença de sistemas referenciais julgados opostos que criam conflitos e provocam ansiedade quando se apresenta a necessidade de interpretar uma ameaça ou surge um sentimento de medo e angústia. $\bigcirc$ recurso aos cultos aos ancestrais ou aos adivinhos é percebido como proibido por alguns membros do grupo doméstico e imprescindível por outros.

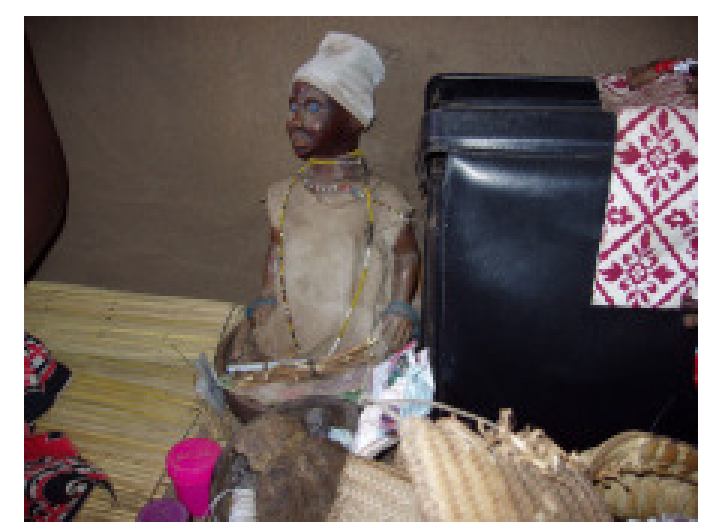

\footnotetext{
${ }^{3}$ Os Ngoni, originários da África do Sul, constituem um grupo dissidente do Reino Zulu que invadiu o Sul e mais tarde se estendeu até o Norte de Moçambique no início do século XIX. Os/as médicos/as tradicionais Ngoni, chamados ngoma, praticavam o kuhlawula, que é a capacidade de interpretar os tinhlolo ou akhata (um conjunto, cujo número varia, de ossos e objetos utilizados - como dados para fazer o oráculo - usados pelo/a médico/a tradicional para identificar as causas dos problemas dos seus clientes).
} 
"O que é invisível, mas intelectualmente e emocionalmente reconhecido por espectadores, deve ser considerado parte da obra de arte" (NOOTER, 1993, p. 57). A figura do nyanga (terapeuta não biomédico) no sul de Moçambique como um ser capaz de controlar as forças visíveis e invisíveis, com potencialidades de circular entre mundos visível e invisível, reverter ações malignas, e restabelecer o equilíbrio individual e social, é sujeito-objeto de contemplação e de compreensão. O seu papel e função social remetem-no a assumir também uma posição ambivalente, ambígua no bem e mal. A "arte" terapêutica do nyanga concebe a pessoa numa perspectiva multidimensional, diferentemente do modelo biomédico, nos seus atos criativos e performativos, em busca de respostas aos males e às incertezas da vida. Na linha de Alfred GELL (1998), que considera a arte como um "sistema de ação, com a intenção de mudar o mundo em vez de codificar proposições simbólicas a respeito dele" (p. 6), o nyanga assume o papel de produtor e depositário da arte. Os objetos adquiridos e criados para seus variados usos pelos terapeutas locais nos ensinam algo sobre as interações humanas e a projeção da sua sociabilidade sobre o mundo envolvente. Na relação entre os seres invisíveis e visíveis as máscaras, ídolos, banquinhos, pinturas, adornos e pulseiras se tornam inteligíveis e devem, portanto, ser analisadas (GELL, 1998, p. 6). Alguns dos objetos terapêuticos artisticamente produzidos são, também, símbolos de poder, de força, de autoridade e sinal de vida (BEWAJI, 2013, p. 197). Entre os nyanga, o xikutsu ou gona, uma cabaça também chamada "filho de Ngoni", é um poderoso objeto que contém medicinais de proteção para o terapeuta e para os que procuram seus cuidados. Este objeto natural, derivado da abóbora, é recriado com extremo cuidado a expressar imagens do real; no caso das imagens (2 e 3), os gona masculino e feminino, é metáfora e metonímia de multiplicidade, fertilidade e prosperidade. O nyanga tem no seu espaço de cura uma série de cabaças contendo medicinais, mas o gona é a mais importante, porque contém o segredo dos nyanga, o mais precioso remédio dos terapeutas, preparado pelo seu mestre e consignado ao graduado publicamente no ato da culminação da iniciação à arte de curar. A fórmula e a composição do poderoso medicinal incluem elementos da fauna, flora e produtos corporais (saliva, sangue, unhas) do novo terapeuta.

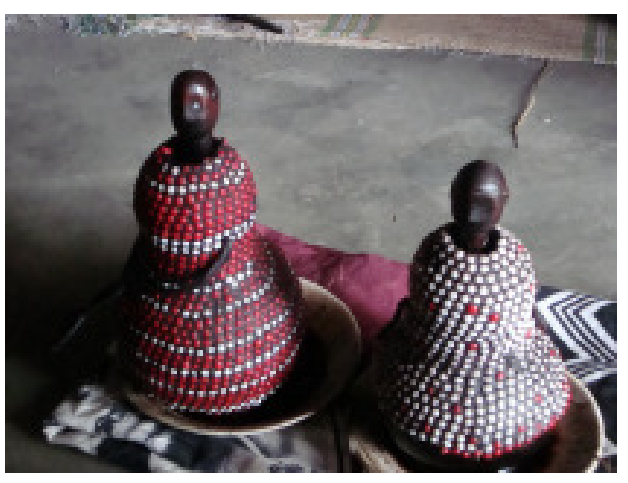

Após a morte do terapeuta, o gona é quebrado (pelo mestre, se possível), simbolizando a morte do seu proprietário e a interrupção da sua atividade. Alguns objetos do defunto (colares, roupas, cabeleiras) são guardados na casa dos familiares sem serem usados, até que um membro da família seja eleito para assumir o trabalho de nyanga. A forma côncava da cabaça reproduz a imagem corporal. À semelhança da configuração do corpo, como um recipiente que, por meio dos seus orifícios e porosidade, pode ser penetrado por substâncias nocivas, ou agentes que sugam energias vitais, causando doenças e morte, há necessidade de ter

cuidados especiais com o corpo e o gona (René DEVISCH, 1993; Esmeralda MARIANO, 2016). Este tipo de objecto tem função social nos processos de cura, é a metáfora do conhecimento "secreto" e fonte de poder terapêutico. Ele serve como agência através da qual as relações complexas de sigilo e divulgação são negociadas e mediadas (NOOTER, 1993, p. 57).

A importância da metáfora não deve ser subestimada, porque é grávida de significados. Uma descrição morfológica de kutshamiwa refere-se a forças sensoriais, como "sugadores de sangue", e a analogias

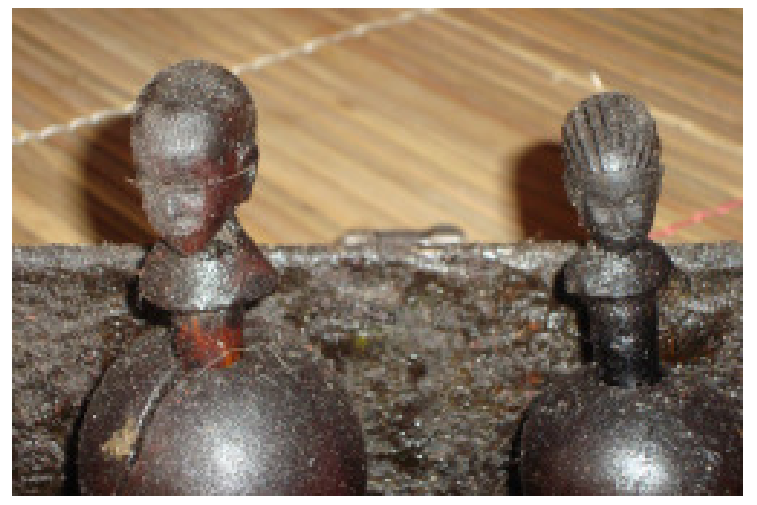
com características de animais. "Pequenas coisas que, se não forem removidas, se reproduzirão" e "pequenos animais negros se movendo dentro do corpo" são frases que evocam a feitiçaria (MARIANO, 2016, p. 312).

A palavra Tsonga para feitiçaria (wuloyl) abrange uma variedade complexa de atos e características, conscientes ou inconscientes, e invisíveis. A inveja, o mau olhado e os atos feitos contra o progresso, prosperidade e sucesso na vida individual e coletiva são expressões de feitiçaria. "O infortúnio, a doença e a morte são, também, frequentemente explicados em termos de feitiçaria" (MARIANO, 2016, p. 312). Kutshamiwa é percebido como sendo uma manifestação de feitiçaria, que descreve a condição de ter um corpo deletério, bem como simboliza a exclusão do corpo aos 
cuidados médicos das vítimas de violência estrutural. Trato kutshamiwa como um conceito de fronteira - por combinar sofrimento físico e diagnóstico social, ao destacar as incertezas e a inquietação moral. Isso requer uma compreensão da moralidade como um "sistema cultural", um "domínio social" e uma "ordem moral local" que envolve experiências em um nível íntimo e é acessível através da etnografia centrada na pessoa, no seu ambiente familiar e social. A referência à feitiçaria permite que um sofredor evite a culpabilização e humilhações, localize a culpa em algum lugar fora do indivíduo - e denota que a desordem física ou social deve ser administrada coletivamente, envolvendo a família e a sociedade como um todo. A interconexão entre o aparecimento de sinais anómalos nos genitais com a feitiçaria, entre as culturas Tsonga, é percebida, também, como punição social deliberada ou não, desencadeada por um ser visível ou invisível.

Essas dimensões ocultas eram, igualmente, exigências para o entendimento das formas de compreensão da loucura pelos habitantes de Songho; sua pesquisa continha a busca por conhecer as linguagens expressivas diversas e as aproximações entre estilos cognitivos (oralidade, visualidade e ritualidade). Tal percurso permitiu pensar possibilidades de recriação ou transcrição entre linguagens, como é o caso das narrativas em forma de contos orais e as narrativas visuais na forma de desenhos, realizados por Allaye Atô, artista da localidade de Yenduma, na falésia Dogon. São meios e figuras trabalhadas como elemento primordial do estar-com na constituição da pessoa e da sociedade, facilitando transfigurações de narrativas específicas através das quais cada sociedade expressa seu mundo imaginal. Elas permitem tecer redes de significados, modos de compreensão e estilos, a fim de apreender o plausível e os possíveis das situações humanas segundo Michel MAFFESOLI (1998) - em tessituras cuja "linguagem [que] conceba a descrição dos fenômenos sociais não há de ser unicamente um 'problema', mas sim uma plataforma a partir da qual vai elaborar-se um exercício do pensamento" (MAFFESOLI, 1998, p. 13). Em ambos os contextos, no Mali e em Moçambique, sob a exportação ocidental dominante, a realidade foi apresentada como qualquer coisa cuja existência tenha, ou possa ser estabelecida de maneira racional e objetiva, representando um mundo dicotômico, demarcando um racionalismo cartesiano e empirismo ocidental (Francis NYAMNJOH, 2001, p. 29).

A análise dos desenhos de Allay Atô como este em que cria uma imagem (1) de yebe-ne ou ginazu (um dos conjuntos de seres não visíveis à maioria dos seres humanos), juntamente com os contos sobre a loucura, sugere uma possibilidade de um campo imaginal, pensado nesta forma de expressão e linguagem que cria pontes para o entendimento comum.

A imagem a seguir é do artista Dogon Alaye Atô, realizada em 1995, no contexto de pesquisa, a fim de recriar interpretações visuais (com hidrocor sobre sulfite) de contos registrados em áudio. A figura é de um ser de cinco cabeças, uma maior olhando para a direita saindo de um corpo meio animal, meio humano. Há duas cabeças bem menores, saindo a primeira da parte inferior de uma barriga volumosa e a segunda é traseira. Outras duas estão em cada um dos pés. A figura tem braço que entrega dinheiro em nota para uma pessoa que vemos apenas parcialmente. Foi digitalizada diretamente do original.

A seguir podemos observar outra criação do artista Dogon Alaye Atô, de 1995. São três seres, todos de perfil, como no desenho anterior. Um deles está no centro, possui três cabeças, duas com chifres e duas asas que cobrem os outros dois seres laterais. $O$ que vemos à esquerda tem uma cabeça, rabo e longo braço-pescoço fino que segura a cabeça grande sobre os joelhos. À direita, observamos uma figura magra com

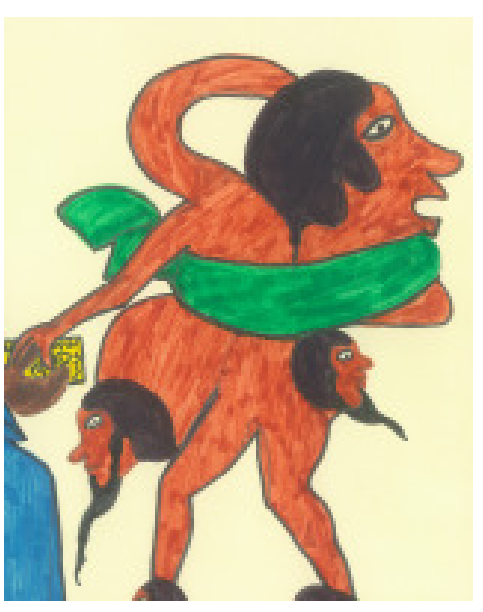
orelhas direcionadas para o alto, bico pronunciado e braços abertos, sugerindo que gesticula ao se comunicar com os demais. Trata-se de uma cena de reunião de um conto entre seres não visíveis que, revoltados com o intenso trabalho devido a pedidos incessantes dos humanos, planejam uma represália.

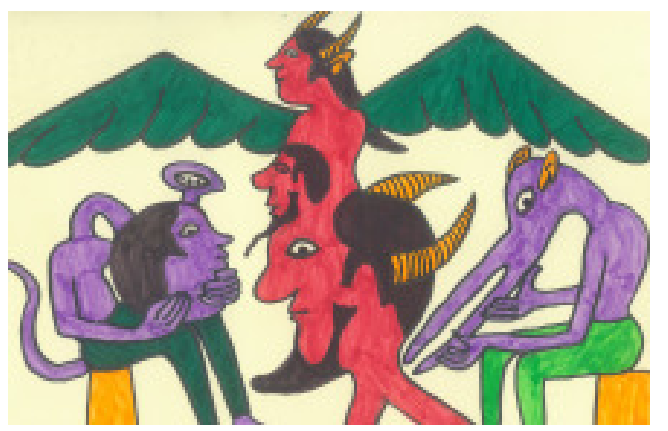

A palavra que se exterioriza nos contos (oral e visual) remete a modos de uma linguagempensamento, a valores e processos que ocorrem no interior das práticas históricas para o entendimento do real. Permite, assim, entrever como a sociedade se confronta com seus problemas, seus próprios impasses, suas explosões e reforça modos do conviver daqueles que compartilham os mesmos mistérios, as mesmas proposições dos quais ele, o conto, é expressão. Como na metáfora, elementos aparentemente distantes nele interagem, desenhando um caminho que permite 


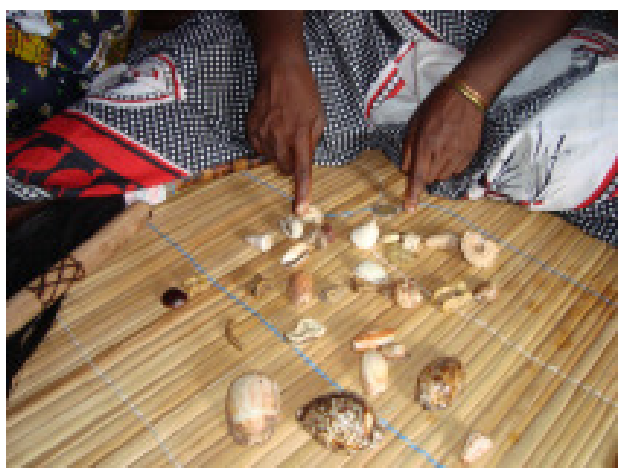

contemplar o inefável, o abstrato, o indizível, num importante processo de comunicação no qual se atribuem sentidos compartilhados à existência. Eles permitem entrever as consequências possíveis das escolhas que se realizam em sociedades, onde todos os domínios da vida são percebidos em uma interação permanente. Como sustenta o camaronês Nyamnjoh (2001, p. 30) e Mbembe (1997), referindose ao princípio camaronês e também em partes do continente africano, as "multiplicidades simultâneas" são todas as dimensões da vida que podem ser articuladas simultaneamente em vários níveis, visíveis e invisíveis. Para o autor, o invisível está no visível, e vice-versa, "não como uma questão de artifício, mas como um e o mesmo como realidade externa simultaneamente - ou como a imagem da coisa e da coisa imaginada ao mesmo tempo" (MBEMBE, 1997, p. 152).

\section{Entremeando caminhos em artes e antropologia}

A migração é outro fenômeno de forte valência afetiva e mobilizador do imaginário para a compreensão das experiências que promove; é também muitas vezes trabalhada nas artes como teatro, narrativas orais e diversas expressões da visualidade (desenho, bordados, cerâmicas, esculturas).

O filme Ganda Amaji foi construído a partir do argumento de Soumaila Karembé, abrindo outras possibilidades de reflexão sobre

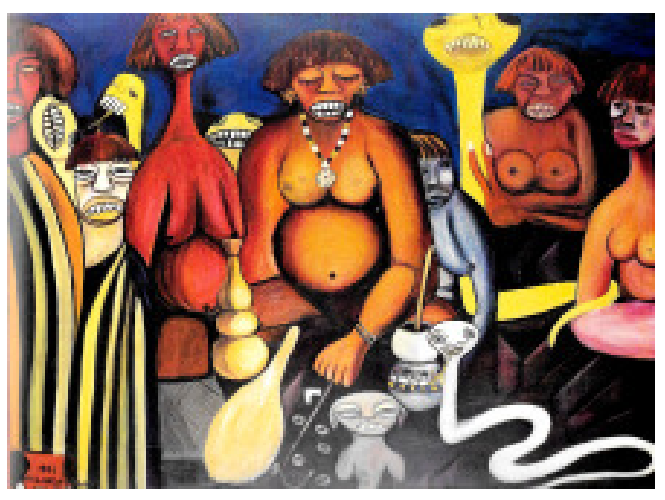
modalidades de interação e metodológicas. Esta

foi uma modalidade de conjugação de passagens intersubjetivas privilegiada para compreensão e discussão sobre o imaginário em torno da migração e de desdobramentos sobre a presença dos jovens na capital, Bamako. Faríamos o filme a partir do argumento de Soumaila e roteiro que deveria respeitar suas propostas juntamente com discussões dos participantes de cada cena/ cenário. A língua seria a de Songho (enjegedomu). Ela foi posteriormente traduzida por um dos colaboradores, também, codiretor de atores, Allaye Yanoge. Todo o elenco foi escolhido por ambos: Soumaila e Allaye. Este último é um animador cultural, envolvido com a organização de grupo de teatro e apresentação de coletivos de músicas e danças em Songho.

Sonhar a cidade, título que atribuíram ao filme, é um exemplo do esforço coletivo de construir pertencimentos múltiplos entre Songho e Bamako. Este processo é evocado aqui a fim de construir questões em torno à intersecção entre arte e antropologia. Há ainda uma dimensão teórica que ressaltamos aqui, acerca da abordagem sobre o contemporâneo (AGAMBEN, 2009) em sua dupla dimensão de ser local e ser universal; em sua singularidade e uma possibilidade do geral, da aventura humana. A pluralização abre espaço para todos, fazendo emergir os descentramentos e as margens.

A temática do filme é a migração contemporânea a partir de uma localidade Dogon para a cidade, neste caso, Bamako, capital do país. Entretanto, é importante destacar aqui que a migração na história Dogon é um fenômeno presente mesmo em sua constituição, uma migração que partiu do Mande integra o discurso de formação de sua unidade. Dogon corresponde a uma formação social da República do Mali, na África Ocidental. Eles ocuparam a região que vai desde os penhascos de Bandiagara, no sudoeste do Níger. São principalmente os agricultores, pastores e ferreiros, mas com intensa atividade turística. Eles ficaram conhecidos pela escultura, ritualidade (sobretudo de fim de luto) e pela grande quantidade de pesquisas, sobretudo etnográficas, voltadas para sua cosmogonia

Desde o período colonial, já havia jovens que deixavam Songho (localidade do planalto Dogon com cerca de dois mil habitantes) em setembro e voltavam em junho do ano posterior ou que distanciaram por períodos maiores que dificilmente ultrapassavam cinco anos sem que alguém de família fossem buscá-los a fim de assumir responsabilidades sociais. A distância, mesmo de anos, não era interpretada como transferência definitiva e nem era admitida desta maneira pelos mais velhos, os quais terminavam impondo, em grande parte das situações, sua decisão de trazer de volta a pessoa que havia migrado. A migração era feita por alguns indivíduos. Com o passar do tempo, porém, aqueles que foram se fixando facilitaram a chegada de outros. 
O fenômeno da migração caracterizado por deslocamentos individuais ou em grupos de jovens motivados, sobretudo, por períodos de seca que ocorreram nas décadas de 1970, 1980 e 1990 e pelos meses de estiagem, não é recente. Entretanto, destacam-se a intensidade e as formas em que estas migrações têm se modificado rapidamente nos últimos trinta anos - passando de migração periódica ao êxodo permanente, de evento raro à atividade obrigatória de jovens, tanto de homens como mulheres.

Nas décadas de 1970 e 1980, as migrações masculinas tinham como destinos preferenciais - Gana e a Costa do Marfim. Mas, já em meados da década de 1990, a capital Bamako passou se a constituir em destino preferencial dos jovens (homens e mulheres). As primeiras mulheres a migrar viajaram para encontrar seus maridos, entretanto, a partir de 1981, as meninas começaram a viajar com seus maridos após o dote (cerca 14 anos) e, com o passar dos anos e as dificuldades crescentes, elas começaram a migrar independentemente dos homens.

O filme desenvolvia-se no mesmo contexto de questões - o movimento de pessoas para Bamako - e sua narrativa desenrolava-se no tempo presente (2003), dialogando diretamente com as entrevistas que havia realizado no momento do campo anterior (2000-2001). As cenas foram realizadas em Songho (antes e depois do retorno da viagem do jovem protagonista) e em Bamako. Além dos diálogos que foram em grande parte improvisadores por cada ator tendo como referência a ideia geral da cena e de seu contexto, as locações e participações secundárias - com uma exceção - eram pessoas de Songho. Eram todos imigrantes que ali trabalhavam no contexto de atividade sazonal ou que haviam se instalado na capital com atividade econômica específica. Mas como foi que Soumaila Karembé concebeu o filme? O que o motivou? Contou ele que

a ideia de trabalhar sobre o filme pode ser que já estive[sse] em minha mente, mas a ideia principal que tive começou talvez com um sonho [...] 'sonhei que me encontrava preso numa mata fechada, ela tinha um vestido todo branco e pergunta: - o que faz aqui? - Ah eu estou aqui, preso e não consigo sair. Eu procuro alguém que irá me salvar. Então, ele jogou um tecido branco em forma de corda. Ela puxou e o tirou dali. Se me ver novamente, irá me reconhecer? - Sim. - Se é assim, a chave de sua vida está comigo. Se eu abrir, você terá sua vida aberta; se fechar, ela também se fecha (Soumaila Karembé, 2009 - Entrevista realizada pela pesquisadora em Songho, Mali, em 9 de janeiro de 2009).

Como definir o filme Ganda Amaji? Seria parte de um processo de metodologia participativa no contexto de uma antropologia partilhada? Forma de retornar à comunidade os resultados de um trabalho? Creio que recupera todas estas dimensões e acrescenta algo diverso.

O imperativo da interpretação apresenta-se no trabalho etnográfico de forma inelutável, já que o/a pesquisador/a não é o único a produzir interpretações sobre grupos sociais, comunidades ou sobre os sentidos de trajetórias pessoais.

Nesta metodologia, ao mesmo tempo de construção de uma narrativa fílmica e de pesquisa etnográfica, as reflexões e interpretações sobre sua realidade caminham ao mesmo tempo em dimensões paralelas, podendo ou não dialogar. Exige, para isto, que a própria pluralidade de perspectivas se transforme em centro de atenção e de análise. O projeto de Soumaila em Ganda Amaji move-se no interior de um universo de interlocução que possui interconexões, mas não coincide com aquele da pesquisadora.

Durante o trabalho etnográfico, como foi sugerido por Maria Luisa Sandoval SCHMIDT (2006), o pesquisador faz um percurso de interpretação diferente do colaborador. Para a pesquisadora,

na situação de campo, [...] pesquisador e colaborador fazem um esforço intelectual, cognitivo e afetivo de mútua compreensão, negociando a pertinência de determinadas temáticas, aprofundando a exposição de modos de sentir e de pensar, retomando aspectos lacunares, obscuros ou intrigantes dos relatos e das observações e reassentando, sempre que necessário, uma espécie de contrato ou pacto de trabalho compartilhado (p. 37).

As subjetividades produzidas nessas trocas frequentemente desiguais fazem parte de um campo de construções de verdades. Além da dimensão e dos interesses individuais, somos sujeitos posicionados, como enfatizou Renato ROSALDO (1984), pois nossos enunciados contêm em si histórias compartilhadas que se entrelaçam, alterando ou transformando a percepção nas relações que estabelecemos com nossos interlocutores. Como enfatizou Clifford (1998), os textos etnográficos são orquestrações de trocas polifônicas em situações politicamente carregadas.

As pesquisas entre os Dogon, baseadas em situações consideradas como "locais", exigiram uma reflexão sobre o contemporâneo que os assumisse como lugares de modernidade, dentro de uma perspectiva e uma dinâmica em que também se interrogue sobre o que é o contemporâneo em seus próprios termos. Ganda Amaji remete a uma de suas expressões, lugares vivos de memória diversa e plural (Pierre NORA, 1984), de alteridades (Marc AUGÉ, 1997), evidenciando os entrelaçamentos de modernidades e rejeitando as reinvenções do exótico. A mobilidade como paradigma conjuga as localidades e globalidades, sem, contudo, desconstruir as hierarquias. $O$ desafio é igualmente compreender as elaborações de questões translocais às quais as sociedades 
devem fazer face, considerando suas respostas e criatividade. Interessa conhecer como são percebidas as questões de desafios comuns às sociedades contemporâneas (considerando os sujeitos individuais e coletivos). O local é, portanto, simultaneamente a construção de uma perspectiva, de um ponto de vista de observação, portanto, um lócus de diálogo, ainda que em interações silenciosas ou silenciadas de experiências históricas contemporâneas. Mbembe (2010) critica a insistência em se pensar as artes africanas a partir de uma oposição entre origem e movimento, enfatizando que a história cultural do continente não pode ser pensada fora do paradigma da itinerância, da mobilidade e do deslocamento.

Ainda é preciso desconstruir a arquitetura política e teórica que associa linearmente o local e o subalterno e a conservação do local e global, do nativo e do cosmopolita, ou seja, o campo do negativo. Ruy Duarte de CARVALHO (2003, p. 91) conta que de passagem por Lisboa é interpelado em seu trabalho sobre os pastores do sul de Angola: "Você, afinal, ocupa-se de coisas, de configurações e de situações tão localizadas que, para nós, nem Angola é... Angola, mesmo, é miséria, confusão, conflito, armas e roque".

\section{Antropologia entre local e global e formas de partilhas: considerações finais}

A cultura da pluralidade é geradora de conexões, organizadora de fluxos do movimento de (des)hierarquizar sentidos, pertencimentos, classes sociais e valores (gênero e raça); de experiências e expressões; de linguagens e símbolos. Na plurividualidade (Massimo CANEVACCI, 2013) de uma economia de vida interconecta se faz arte-composição na polifonia, criam-se espaços-constelações de sentidos que, mesmo fugazes, representam fluxos de movimentos que, como tais, irão permanecer como experiência transformadora, autoplurieducativa (Paulo FREIRE, 2002).

Há uma ética e uma estética do inacabamento humano que é potencializado. Ética e estética se intercruzam e se conflituam num campo de interações altamente competitivas e violentas, onde a ambição pelo poder gera disparidades visíveis entre ricos e pobres, o bem-estar volátil, e os mecanismos e as dinâmicas do poder permanecem ocultos. West, na esteira de Mbembe, particularmente em contextos africanos, chama atenção sobre a necessidade de se cultivar "outras linguagens" que expressem éticas políticas localmente emergentes, surgidas da vida diária das pessoas, que abordam os medos e pesadelos quotidianos e as imagens através das quais as pessoas as expressam ou sonham (WEST, 2009). Nos discursos sobre a feitiçaria analisada por West, emergem múltiplas linguagens de poder entre os habitantes do planalto de Mueda, na província de Cabo Delgado, ao norte de Moçambique. A transformação neoliberal da economia e política moçambicana nos anos 80 criou um campo fértil para a criatividade das narrativas e de alegorias manifestas na vida dos seus habitantes de Cabo Delgado e de outras partes de Moçambique. O autor, seguindo as falas dos seus interlocutores, revela que a democracia é entendida como um direito de cada um "acreditar naquilo em que acredita" (WEST, 2008, p. 349), porque na democracia tudo é permissível, como o excerto a seguir ilustra:

Há gerações que os habitantes de Mueda suspeitam de que alguns de entre eles são capazes de fazer leões ou de se transformarem neles. Pela sua definição, os feiticeiros realizam atos espantosos para se alimentarem do bem-estar dos outros, mas, de acordo com a maioria das pessoas com quem trabalhei, esse fenómeno intensificou-se muito nos anos recentes, tomando dimensões novas e alarmantes (p. 348).

No contexto de uma ética neoliberal dominante, as pessoas buscam criativamente capacidades para resistir às desigualdades continuamente emergentes, e formas de apropriação de novos recursos, fazendo sentido a análise das linguagens da feitiçaria como uma possibilidade de compreender as ações e interações humanas. Porque ainda são imensos os desafios dos processos democráticos, nas abordagens sobre os direitos humanos em contextos como o sulafricano, moçambicano e brasileiro, há espaço para reflexão sobre o imaginário e as interações, para a aprendizagem sobre o visível e o invisível. Outras múltiplas dimensões da sexualidade, homofobia, racismo e exclusão devem ser, igualmente, incluídas nas reflexões a fim de alargar nossos horizontes sobre zonas da invisibilidade. As experiências na África do Sul mostram que, apesar de mais de três décadas terem passado desde a descriminalização da sexualidade homoafetiva, as lésbicas negras ainda sofrem várias formas de violência, lutam exigindo seus direitos para aceder a espaço de visibilidade pública e serem escutadas à semelhança dos gays e lésbicas de raça branca. A ativista e académica sul-africana Matebeni (2017, p. 32) criativamente ilustra o banheiro da cidade rica "dos brancos" como um espaço onde a beleza e a felicidade são exaltadas pelas lésbicas negras provenientes de bairros suburbanos pobres, mas também, como um lugar onde a violenta lembrança de direitos inacessíveis é visualizada.

Thaís TIRIBA e Laura MOUTINHO (2017) oferecem elementos interessantes da pluralidade da cultura como produtora e marcadora de diferenças de gênero e raça, mas, também, como geradora de conexões veiculadas pelas experiências de Matebeni - lésbica, negra, ativista e académica 
sul-africana. De suas narrativas - publicadas como entrevista pelas autoras citadas anteriormente - há ricos e numerosos inputs, dos quais captamos dois aspetos valiosos para a aproximação das nossas experiências de pesquisas. 1) A plasticidade do corpo, o qual, num determinado espaço em interação com outros corpos, se transforma, modifica nossos quadros cognitivos e cria espaçosconstelações de sentidos. Ser lésbica e negra, num espaço universitário e heteronormativo, faz com que o corpo e a existência se tornassem texto, abrindo espaço para um conhecimento compartilhado mais amplo e diversificado; 2) as fronteiras da oralidade e da linguagem abrem outras possibilidades criativas, presentes nas interações humanas. Matebeni (2017) aponta a barreira linguística nos intercâmbios Sul-Sul, onde as traduções, por exemplo, podem distorcer o sentido mais profundo da realidade, quando se inserem interpretações ocidentais às nuances que existem em nossas realidades. A proposta criativa desta cientista social, para superar os limites da língua e da linguagem, também válida e compartilhada na nossa análise, é o recurso à visão e às visualidades, através de "metáforas visuais".

\begin{abstract}
Se por vezes não pudemos nos comunicar pela língua falada, o jeito com que olhávamos umas às outras e umas com as outras levaram-me a perceber que existe uma riqueza de conhecimento que juntas poderíamos gerar. Nós precisamos estar mais atentas às formas e aos métodos de trocarmos e compartilharmos nossos olhares. Esses para mim são novos insights para a criação de conhecimentos múltiplos. É importante investirmos conjuntamente nessas estratégias (TIRIBA; MOUTINHO, 2017, p. 185).
\end{abstract}

Nos limites da língua, da oralidade e visualidade, desenvolvem-se e fazem-se recurso a outros múltiplos sentidos. A mobilidade de Esmeralda Celeste Mariano, moçambicana e negra, e Denise Dias Barros, brasileira e branca, em diferentes espaços geográficos e culturais, mostra a plasticidade do corpo, na representação do sensível, ou na documentação das experiências que se relacionam ou podem ser apreendidas através dos sentidos em contextos de língua falada ou não, através de um processo de aproximação, de partilha e negociação de múltiplas formas de estar e ser no mundo.

\title{
Referências
}

ABU-LUGHOD, Lila. Veiled Sentiments: Honor and Poetry in a Bedouin Society. Berkeley: University of California Press, 1986.

ADICHIE, Chimamanda. "O perigo de uma única história". TED, 07/10/2009. Disponível em https:// www.youtube.com/watch?v=D9lhs241zeg.

AGAMBEN, Giorgio. O que é o contemporâneo? e outros ensaios. Chapecó: Argos, 2009.

AUGÉ, Marc. Les guerres des rêves. Exercices d'ethno-fiction. Paris: Seuil, 1997.

BARROS, Denise Dias. Itinerários da loucura em territórios Dogon. Rio de Janeiro: EDFIOCRUZ, 2004. (Coleção Loucura \& Civilização) Disponível em http://books.scielo.org/id/97dxr/pdf/barros9788575413326.pdf.

BARROS, Denise Dias. "Liens ville-village et changements sociaux face à la migration saisonnière. Le mouvement de personnes entre Songho (Région Dogon) et Bamako, Mali”. Anthopos, n. 105, p. 471-488, 2010.

BARROS, Denise Dias; ABDALLA, Mustafa. "The Resonance of Travel in a Dogon Village. Pilgrimage Experience, Mobility and Social Change in Songho, Mali". In: ABDALLA, Mustafa; BARROS, Denise Dias; BERTHET, Marina (Orgs.). Spaces in Movement. New Perspectives on Migration in African Settings. 1. ed. Köln: Rüdiger Köppe Verlag, 2014. p. 57-78.

BARROS, Denise Dias; BAHI, Aghi; MORGADO, Paula. "Dogonicité et internet: une lecture critique de la substantivation des identités". Anthropologie et Société, n. 35, p. 69-86, 2011.

BAYART, Jean-François. “Préface à la nouvelle édition: 'Comme vous en Afrique' ou l'hégémonie dans l'extraversion". In: BAYART, Jean-François. L'État en Afrique. La politique du ventre. Paris: Fayard, 2006.

BATESON, Gregory. La Nouvelle Communication. Paris: Seuil, 1981.

BEWAJl, John Ayotunde Isola. Black Aesthetics: Beauty and Culture. New Jersey: Africa World Press, 2013.

BOURDIEU, Pierre; WACQUANT, Loïc. Pour une anthropologie réflexive. Paris: Seuil, 1992.

BOURRIAUD, Nicolas. Formas de vida: a arte moderna e a invenção de si. Tradução de Dorothée de Bruchard. São Paulo: Martins Fontes, 2011 a. (Coleção Todas as Artes) 
BOURRIAUD, Nicolas. Radicante: por uma estética da globalização. Tradução de Dorothée de Bruchard. São Paulo: Martins Fontes, 201 1b. (Coleção Todas as Artes)

CANEVACCI, Massimo. Sincretika: explorações etnográficas sobre artes contemporâneas. São Paulo: Studio Nobel, 2013.

CARVALHO, Ruy Duarte de. Actas da Maianga ... dizer das guerras, em Angola... Lisboa: Cotovia, 2003.

CLIFFORD, James. "Sobre a autoridade etnográfica". In: CLIFFORD, James. A experiência etnográfica: antropologia e literatura no século XX. Rio de Janeiro: EDUFRJ, 1998. p. 17-62.

CLIFFORD, James; MARCUS, George E. (Orgs.). Writing Culture. The Poetics and Politics of Ethnography. Berkeley: University of California Press, 1986.

COMAROFF, Jean; COMAROFF, John. "Etnografia e imaginação histórica". Tradução de Iracema Dulley e Olívia Janequine. Revista Proa, v. 1, n. 2, 2010. Disponível em http://www.ifch.unicamp.br/ proa. Acesso em 13/10/2018.

CRAPANZANO, Vincent. Imaginative horizons: an essay in literary-philosophical anthropology. Chicago e Londres: University of Chicago Press, 2004.

DEVISCH, René. Weaving the Threads of Life: The Khita Gyn-Eco-Logical Healing Cult Among the Yaka. Chicago: The University of Chicago Press, 1993.

FREIRE, Paulo. Pedagogia do oprimido. 34. ed. São Paulo: Paz e Terra, 2002.

GANDA Amaji - Rêves d'un jeune Dogon à Bamako. Direção: Gianni Puzzo, Denise Dias barros. Mali/Brasil. Anthares multimeios/Casa das Áfricas [mombo, francês], 70min, 2006. (Audiovisual vinculado a projeto de pesquisa de Denise Dias Barros).

GELL, Alfred. Art and Agency: an anthropological Theory. Oxford: Oxford University Press, 1998.

HOUSEMAN, Michael; SEVERI, Carlo. Navenou le Donner à Voir. Essai d'Interprétation de l'Action Rituelle. Paris: CNRS-Éditions de la Maison des Sciences de l'Homme, 1994.

KLEIN, Renate Duelli. "How to do What we want to Do". In: BOWLES, Gloria; KLEIN, Renate Duelli (Orgs.). Theories of Women Studies. London: Routledge \& Kegan Paul, 1983.

MAFEJE, Archie. Anthropology in post-independence Africa: end of an era and the problem of selfredefinition. Kenya: Heinrich Böll Foundation, 2001.

MAFFESOLI, Michel. Elogio da razão sensível. Tradução de Albert Christophe Migueis Stuckenbruck. Petrópolis: Vozes, 1998.

MARCUS, George. Ethnography through Thick and Thin. Princeton: Princeton University, 1998.

MARCUS, George. "O intercâmbio entre arte e antropologia: como a pesquisa de campo em artes cênicas pode informar a reinvenção da pesquisa de campo em antropologia". Rev. Antropol., São Paulo, USP, v. 47, n. 1, p. 133-158, 2004. Disponível em http://www.scielo.br/pdf/ra/v47n1/a04v47n1 .pdf.

MARCUS, George; FISCHER, Michael. Anthropology as a Cultural Critique: An experimental moment in the Human Sciences. Chicago \& London: Chicago University Press, 1986.

MARIANO, Esmeralda. "Ser antropóloga entre local e global". Revista de Antropologia, v. 60, n. 30, p. 65-88, 2017. (Dossiê: Olhares cruzados para a África: trânsitos e mediações)

MARIANO, Esmeralda. "The 'Unsaying' of Reproductive Affliction in Mozambique Witchcraft and Local Reproductive Knowledge". The Oriental Anthropologist, v. 16, n. 2, p. 261-278, 2016.

MATEBENI, Zethu. "Perspectivas do Sul sobre relações de gênero e sexualidades: uma intervenção queer". Revista de Antropologia, v. 60, n. 30, p. 26-44, 2017. (Dossiê: Olhares cruzados para a África: trânsitos e mediações)

MBEMBE, Achille. The "thing" and its double in Cameroonian cartoons". In: BARBER, Karin (Org.). Readings in African Popular Culture. Oxford: James Currey, 1997. p. 151-163.

MBEMBE, Achille. Sortir de la grande nuit. Paris: La Découverte, 2010. 
MORIN, Edgar. Método I: a natureza da natureza. Mira Sintra: Europa-América, 1987.

NEVES, Paulo Sérgio da Costa; MOUTINHO, Laura; SCHWARCZ, Lilia Katri Moritz. "Herança colonial confrontada: reflexões sobre África do Sul, Brasil e Estados Unidos". Revista Estudos Feministas, Florianópolis, v. 27, n. 3, e66960, 2019.

NJOKU, Francis O. C. "The Originality of African Philosophy as a Hermeneutical Problem in Okere". In: OGUEJIOFOR, Josephat Obi; ONAH, Godfrey Godfrey Igwebuike (Eds.). African Philosophy and the Hermeneutics of Culture. Essays in Honour of Theophilus Okere. Munster: Studies in African Philosophy, 2005. p. 93-111.

NORA, Pierre. "Présentation”. In: NORA, Pierre (Org.). Les Lieux de Mémoire, v. I. Paris: Editions Gallimard, 1984.

NOOTER, Mary H. "Secrecy: African Art That Conceals and Reveals". African Arts, v. 26, n. 1, p. 54-69, 1993.

NYAMNJOH, Francis B. "Delusions of development and the enrichment of witchcraft discourses in Cameroon". In: MOORE, Henrietta L.; SANDERS, Todd (Orgs.). Magical interpretations, material realities: modernity, witchcraft, and the occult in postcolonial Africa. London and New York: Routledge, 2001. p. 97-117.

ROSALDO, Renato. "Grief and the headhunter's rage". In: BRUNER, Jerome (Org.). Text, play and story. Washington: American Ethological Society, 1984. p. 178-195.

SCHMIDT, Maria Luisa Sandoval. "Pesquisa participante: alteridade e comunidades interpretativas". Psicol. USP, v. 17, n. 2, p. 11-41, 2006. Disponível em http://www.scielo.br/scielo.php?pid=S0103$65642006000200002 \&$ script $=$ sci_abstract\&tIng $=$ pt.

THORNTON, Robert. "The transmission of knowledge in South African Traditional Healing". Africa, v. 79, n. 1, p. 17-34, 2009. Disponível em https://www.cambridge.org/core/journals/africa/article/ transmission-of-knowledge-in-south-african-traditional-healing/AB7496C545C21C7A2045083D7D FC359B.

TIRIBA, Thais Henriques; MOUTINHO, Laura. "Olhares compartilhados: (des)continuidades, interseccionalidade e desafios da relação Sul-Sul. Entrevista com Zethu Matebeni". Revista de Antropologia, v. 60, n. 3, p. 181-185, 2017. (Dossiê Olhares cruzados para a África: trânsitos e mediações)

THIONG'O, Ngugi Wa. Decolonising the Mind: the politics of language in African literature. London: Heinemann, 1986.

WEST, Harry G. Kupilikula: o poder e o invisível em Mueda, Moçambique. Lisboa: ICS, 2009.

WEST, Harry G. "Governem-se vocês mesmos!". Democracia e carnificina no Norte de Moçambique. Análise Social, v. XLIII (2), p. 347-368, 2008.

Denise Dias Barros (ddbarros@usp.br) é doutora em Sociologia pela Universidade de São Paulo. Aposentou-se pela Universidade de São Paulo, onde trabalhou entre 1985 e 2015. Atua como orientadora no Programa de Pós-Graduação Interunidades em Estética e História da Arte da USP. Realizou pesquisas sobre o tratamento social da loucura, migração, arte e antropologia, tendo como campo a sociedade Dogon, Mali. Desde 2010, dedica-se a estudos sobre expressões culturais tamacheque e mobilidade no continente africano.

Esmeralda Celeste Mariano (esmeraldamariano3@gmail.com) é doutora em Antropologia Social e Cultural pela Universidade KU Leuven, Bélgica. Desde 2005 é docente no Departamento de Arqueologia e Antropologia da Faculdade de Letras e Ciências Sociais, Universidade Eduardo Mondlane. Realiza pesquisas sobre corpo, saúde, medicina endógena, dinâmicas de gênero e sexualidade, formas de violência, conhecimento de patrimônio natural e marinho no Canal de Moçambique. 


\section{COMO CITAR ESSE ARTIGO DE ACORDO COM AS NORMAS DA REVISTA}

BARROS, Denise Dias; MARIANO, Esmeralda Celeste. "Experiências que tangenciam o (in)visível e a mobilidade: etnografias em diálogo". Revista Estudos Feministas, Florianópolis, v. 27, n. 3, e66982, 2019.

\section{CONTRIBUIÇÃO DE AUTORIA}

Denise Dias Barros: elaboração conceitual, construção de parte dos dados relativos à sociedade Dogon/Mali, redação.

Esmeralda Mariano: elaboração conceitual, construção de parte dos dados, redação.

\section{FINANCIAMENTO}

Projeto PROÁFRICA coordenado por Laura Moutinho.

\section{CONSENTIMENTO DE USO DE IMAGEM}

Não se aplica. As imagens foram realizadas pelas autoras.

APROVAÇÃO DE COMITÊ DE ÉTICA EM PESQUISA

Não se aplica.

\section{CONFLITO DE INTERESSES}

Não se aplica.

\section{LICENÇA DE USO}

Este artigo está licenciado sob a Licença Creative Commons CC-BY International. Com essa licença você pode compartilhar, adaptar, criar para qualquer fim, desde que atribua a autoria da obra.

HISTÓRICO

Recebido em 09/08/2019

Aprovado em 23/08/2019

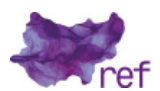

